\title{
Black - White Intergroup Relations in France. The Impact of Antiracist Norm and Categorization Process using the RepMut Tool
}

\author{
By Carlos Roberto Velandia Coustol \\ Philippe Castel ${ }^{\dagger}$ \\ Marie Francoise Lacassagne $e^{t}$
}

\begin{abstract}
The aim of this research is to characterize Black-White interethnic relations in France, differentiating between the weight of the antiracist norm and the categorization effects. The specificity of this study is based on the methodology used to understand these relationships. Our methodology, which uses the RepMut tool, allows us to identify intergroup relations based on data produced and evaluated by the two groups studied. The results of our approach show a) an in-group favoritism strategy for the Black group underpinned by conventional mechanisms of categorization, b) an out-group favoritism strategy for the White group underpinned by the antiracist norm. The discussion focuses on the antiracist norm and its implications for understanding intergroup relations according to the specific context of interethnic relations.
\end{abstract}

Keywords: black-white interethnic relations, France, intergroup relations, RepMut, social categorization

\section{Introduction}

\section{The French Context}

It is difficult to quantify the black population present on the French territory insofar as the Constitutional Council of November 15th 2007 declared ethnic statistics to be "unconstitutional". However, a black population clearly exists. The National Institute of Statistics and Economic Research (INSEE) estimated the French population as at January 1st 2014 to be 65,821,000, divided into three groups: French, Foreigners and Immigrants.

In terms of the French people, $89.73 \%$ of them are French by birth and $4.4 \%$ by acquiring nationality. Whatever the category (French by birth or by naturalization), $11 \%$ of French people are direct descendants of one or two immigrant(s), and among the children of immigrants between 18 and 30 years of age, half has African origins (Borrel and Lhommeau 2010, INSEE 2014).

${ }^{*}$ PhD Student, Burgundy University, France.

${ }^{\dagger}$ Full Professor, Burgundy University, France.

${ }^{\star}$ Full Professor, Burgundy University, France. 
Foreigners represent $5.80 \%$ of the population living in France, of which $13 \%$ are from sub-Saharan Africa.

Lastly, Immigrants represent $8.38 \%$ of the total French population. Details by country of birth show that $42 \%$ of immigrants come from Africa. Specifically, $29.8 \%$ of the total immigrants of France come from Maghreb countries and $13 \%$ from sub-Saharan Africa.

Despite the willingness displayed in law to integrate all citizens into the French Republic regardless of their origin, immigrants and their descendants are victims of discrimination. The TeO Survey ${ }^{1}$ (Beauchemin et al. 2010), conducted on a sample base of immigrants and their descendants $(\mathrm{N}=22,000)$ in mainland France, identified that the reasons for discrimination reported most frequently were nationality (37\%) and skin color (20\%). In greater detail, the survey identified that people connected with sub-Saharan Africa or a $\mathrm{DOM}^{2}$, whether because they themselves or their parents were born there, reported most frequently having experienced racist behavior and were the least likely not to have felt exposed to racist behavior. They associated this racist behavior

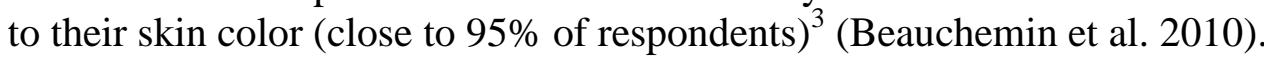

The results of this survey can be explained at a socio-psychological level by automatic mechanisms activated in intergroup relations. In fact, insofar as "being black" in mainland France (or "being white" in a DOM) makes the Black category (or White category) the prominent category, the theories of social categorization (Tajfel 1972, 1978) suggest that the conditions for the emergence of the underlying mechanisms of discrimination are present.

Nevertheless, the effects of these mechanisms can be strengthened or weakened by the norms of force in the country in question. In the case of France, two norms appear to clash: on one hand, a "racist" norm linked to the colonization of a vast part of the African continent which can be translated even at the present time by the separation in the collective imagination of the DOMs and mainland France, and, on the other hand, an anti-racist norm enacted at a legislative level (Pleben law); since July $1^{\text {st }} 1972$, racism is a crime punishable by law, with penalties ranging from a fine of 750 euros (non-public racial insult) to a one year prison sentence (public racial defamation).

\footnotetext{
${ }^{1} \mathrm{TeO}$ : Trajectories and Origins. Survey on Population Diversity in France.

${ }^{2}$ Départements d'outre-mer ; In English "Overseas territories of France"

3 "Les personnes ayant un lien avec l'Afrique subsaharienne ou un DOM, qu'elles-mêmes ou leurs parents y soient nées, déclarent plus fréquemment avoir vécu une expérience raciste et sont les moins nombreuses à ne pas avoir le sentiment d'y être exposées. Elles rapportent ces expériences racistes à leur couleur de peau (près de $95 \%$ d'entre elles)" (Beauchemin et al. 2010: 135)
} 


\section{Theoretical Framework}

Racism implies: a) the shared certainty that there are ethnic categories defined $a$ priori by characteristic traits, b) the belief that these traits establish a difference between two groups: the members of the other category being inferior, less good or non-existent (Castel and Lacassagne 2011) and c) the belief that this asymmetry legitimately establishes advantages or privileges for the discriminating group and/or disadvantages for the discriminated group (Dovidio et al. 2010a, Dovidio et al. 2010b).

However, it is possible to identify different forms of racism, namely racism and subtle racism.

Blatant racism is the visible and conscious manifestation of the exercise of power to favor one group over another (Dovidio et al. 2010a, Ndobo 2010). Subtle racism is also expressed by negative attitudes or by the absence of positive feelings toward a person or a group. The reasons given for this different treatment are based on beliefs other than the existence of "races" and a hierarchy between them. This kind of racism is less frequent and less intense. (e.g. when in a selection process for a job, between two candidates with equivalent curriculum vitae and equivalent selection interviews, the manager person will select the candidate of their in-group, justifying his/her choice by criteria not being part of those initially established (without reference to ethnicity of the candidate of the out-group).

Racism, whatever its form and its social integration, uses fundamental mechanisms which have been studied for some fifty years within the framework of social categorization.

The early work of Tajfel, initiator of socio-cognition, identified different behaviors that the human being adopts when he considers himself a member of a group following a categorization differentiating his group (in-group) from another group (out-group).

Among the mechanisms underlying these behaviors, in-group favoritism and out-group de-favoritism are evaluative or behavioral biases that lead individuals to favor the members of their in-group and/or discriminate against those of the other group; the combination of these two biases accentuate the gap between his group and the other group (Tajfel et al. 1971). In other words, social categorization reflects the fact that the treatment following a categorization is expressed not only by the act of favoring the in-group (us), but also sometimes by negative behaviors being produced toward members of the out-group (them), which is more commonly called discrimination (Bourhis and Leyens 1999).

In the case of the Black-White categorization, the categorization phenomena are even more powerful as they are based on natural categories (Brewer 1979, Rothbart and Taylor 1992). In fact, stereotypes and selfstereotypes are more prominent and more vigorous when the people belonging to the social groups in question can be identified through their physical characteristics such as gender, age and other visible attributes (Bourhis and Gagnon 2006, Fiske 1998). 
A body of work grouped under the heading of meta-theory of social identity (Abrams and Hogg 2004, Haslam 2004, Hogg et al. 2004) highlighted the role of identity in these discriminatory behaviors. According to these authors, the human being is constantly seeking a positive identity and it is prepared to achieve this using a number of strategies called "identity management strategies" (Ellemers 1993, Van Knippenberg and Dijksterhuis 2000, Van Knippenberg 1978). These strategies can be seen, for example, in a situation where "being black" could be disadvantaging: a black person could choose to identify himself/herself as an individual rather than as a member of "Black group" ("I am not black, I'm before all me, a human being").

In a society where an antiracist norm prevails, the positions of Black and White identities cannot be symmetrical:

- For Black people, given France's colonial past, the norm may bring back feelings of inequality in Black/White relations because white people need a law to reestablish equality. In other words, it is unlikely that this norm gives black people a positive identity.

- For White people, the adoption of the antiracist norm is a way to make themselves feel good. Indeed, if they willingly accept it, they are not subject to any authority; furthermore, in "race" relations, the norm lets them play "the good guy".

\section{Our Research}

The aim of this research is therefore to understand Black-White relations in France by separating the effects of the antiracist norm (based on Black/White relations) from those of the category-based discrimination (based on in-group vs. out-group relations) ${ }^{1}$.To achieve this objective, we propose an exploration of those particular intergroup relations on a university context, based on representations of the relations of the two groups. To access the representation of these relations, each of the two groups (Black and White) would be asked to give the characteristics specific to their group and the other group, and to make judgments based on these characteristics.

We expect that, despite the fact that black and white people are subject to the same psychosocial laws and face similar life contexts, they will have different representations of the relations between the two groups. We expect, notably, that white French participants, depending very highly on the antiracist norm to acquire or maintain a positive identity, adhere more to this norm than black people who, being somehow the "beneficiaries", find themselves in a less satisfactory social position from the perspective of identity, which may enforce their feeling discrimination.

\footnotetext{
${ }^{1}$ This study is developed in a context of a larger research aimed at understanding the relations between French-speaking Sub-Saharan Africans and French nationals in Burgundy, that is the reason why all the Black participants are citizens of African countries and all the White participants are French citizens.
} 


\section{Method}

We used a specific methodology which has been recently developed to consider the views of the invited groups. This methodology is called Mutual Representations (RepMut) ${ }^{1}$. The RepMut methodology constitutes an intergroup relations analysis tool, taking the form of a questionnaire in its data collection phase. It uses the various advances on the social categorization model, incorporating a part of the methodology of social representations (Abric 1984, Flament 2001, le Bouedec 1984, Moscovici 1984) and the notion of co-construction produced from the social psychology of language (Ghiglione and Blanchet 1991, Ghiglione 1988).

In the case of our study, the RepMut tool takes into account the representations that each group (Black or White) makes about the members of its category (in-group) and those of the other category (out-group).

Voluntary participants were questioned as members of one of the categories studied (Black or White).

Two kinds of information were collected:

1. Representations: Each subject assigned five adjectives to describe the other category (out-group representation) and its own category (ingroup-representation) ${ }^{2}$. The adjectives produced constituted the content of the representation. This part of the results of the RepMut methodology is not addressed in this document, but some adjectives are presented as examples.

2. Estimations: Each subject had to evaluate the adjectives they had cited and indicate whether the characteristics were judged to be negative or positive (scale of -100 to +100$).^{3}$

This methodology can be described as non-directive insofar as the representational content (and corresponding estimations) are supplied exclusively by the participants themselves. The RepMut methodology provides access in a unique questionnaire to stereotypes (by the adjectives given by participants) and the values associated with those adjectives (by the estimations). In that way, the content of RepMut results are as free as possible of researcher representations and judgments, and ensure a neutral approach in regard to themes particularly contentious or subject to social desirability.

\section{Participants}

115 people $\left(M_{\text {age }}=24.95 ; S D=10.51\right)$ were contacted individually at the University of Burgundy based on belonging to one of the two categories. They were contacted at university library or computer rooms during their personal

\footnotetext{
${ }^{1}$ Représentations Mutuelles (in French). RepMut is a tool that has been developed based on the design of social partitions (Castel and Lacassagne 2011) by a working group (mainly Castel P, Lacassagne MF, Mangin F, Peteuil A, Velandia-Coustol C) from the SPMS laboratory

${ }^{2}$ Other representations were collected but are not discussed in this article.

${ }^{3}$ Other measures have been requested but are not discussed in this article.
} 
work time. No questions about their academic field or status (student, teacher and/or, researcher) were demanded.

- Black: $(\mathrm{n}=30), M_{a g e}=24.40 ; S D=5.36$. They are all African (residing in France) of different nationalities (average time of residence in France $=10.60$ years; $S D=8.75 ; M d n=6.50)$.

- White: $(\mathrm{n}=85), M_{\text {age }}=25.15 ; S D=11.82$. They are all European, of French nationality.

The two sample groups are not equivalent in size due to the disparity between these two populations within the University of Burgundy; however, the number of participants in each group is satisfactory from a statistical analyses perspective.

Although the various African cultures differ considerably from each other, African participants share a common experience, namely to adapt their categorical identity of "Black" to a predominantly "White" relational context, according with Fiske (1998) and Bourhis and Gagnon (2006)

\section{Procedure}

The participants responded to the RepMut tool, taking the form of a questionnaire related to skin color forming part of a study on relations between different groups in France (average completion time: 20 minutes).

\section{Processing of the Data and Format for the Presentation of the Results}

The dependent variable (estimation) consists of two indicators: the outgroup estimation and the in-group estimation. For each indicator, this is the arithmetic mean of the values assigned by the participants of each source group, in the self-evaluation of the adjectives used to define each target group. Three effects must be considered in the estimations by source group and target group:

Baseline estimation: major effect concerning the source groups. This effect reflects the differences in evaluation; theoretically, it reflects the use or not of the same frame of reference.

Prejudgment: major effect of the target groups. This effect reflects the prejudgments, or even prejudices, existing against a group (quantitative estimation of prejudice associated with each group).

Categorization: interaction effect (numerical discrimination index) reflecting the effects of categorization.

For the significance tests, since the conditions of normality of distribution and equality of variance were not fulfilled, we used non-parametric tests: Mann Whitney for comparisons between independent groups and Wilcoxon for comparisons of repeated measures. For the $p$ values, we chose the threshold of $\mathrm{p}<.05$ and the size of the effect $r$ was calculated by dividing $\mathrm{Z}$ by the square root of $\mathrm{N}(\mathrm{r}=\mathrm{Z} / \sqrt{ } \mathrm{N})$. 


\section{Results}

Table 1. Average Estimation Scores (and Standard Deviations) based on Belonging to the Source Group (Black vs White) and Belonging to the Target Group (Black vs White)

\begin{tabular}{|c|c|c|c|}
\hline $\begin{array}{l}\text { Source } \rightarrow \\
\text { Target } \downarrow\end{array}$ & $\begin{array}{l}\text { BLACK } \\
(\mathbf{n}=\mathbf{3 0})\end{array}$ & $\begin{array}{l}\text { WHITE } \\
(\mathbf{n}=\mathbf{8 5})\end{array}$ & $\begin{array}{l}\text { OUT-GROUP } \\
\text { ESTIMATION } \\
\mathbf{3 2 . 1 2} \text { (41.62) }\end{array}$ \\
\hline BLACK & $35.11(53.97)$ & $42.45(32.98)$ & $\begin{array}{l}\text { BLACK } \\
\text { PREJUDGMENT } \\
40.53(39.40)\end{array}$ \\
\hline WHITE & $2.87(49.61)$ & $7.96(47.84)$ & $\begin{array}{l}\text { WHITE } \\
\text { PREJUDGMENT } \\
6.63(48.14)\end{array}$ \\
\hline TOTAL & $\begin{array}{l}\text { BLACK BASELINE } \\
\text { ESTIMATION } \\
\mathbf{1 8 . 9 9 ( 5 3 . 9 0 )}\end{array}$ & $\begin{array}{l}\text { WHITE BASELINE } \\
\text { ESTIMATION } \\
\mathbf{2 5 . 2 0}(\mathbf{4 4 . 4 7 )}\end{array}$ & $\begin{array}{l}\text { IN-GROUP } \\
\text { ESTIMATION } \\
\mathbf{1 5 . 0 4 ( 5 0 . 7 0 )}\end{array}$ \\
\hline
\end{tabular}

In terms of the Baseline Estimation index, a statistical analysis (Mann Whitney) shows no significant difference either for the participants as a whole or in an analysis by the target group.

In terms of the Prejudgment index, the Wilcoxon test shows significant differences between the Black target group $\left(M=40.53\right.$; $\left.M d n_{\text {targetBlack: }} 40.00\right)$, and the White target group $\left(M=6.63 ; M d n_{\text {targetWhite: }} 0.00\right) \mathrm{Z}=5.981, p=.0000$, $r=.55$, the effect is important. Prejudice toward black people is more favored than prejudice toward white people, and this effect is found for each source group.

For all participants, the Out-group Estimation $\left(M_{\text {OUT }}=32.12, M d n_{\text {OUT }}\right.$ $=33.33)$ is higher than the In-group Estimation $\left(M_{I N}=15.04, M d n_{I N}=10.00\right)$, the effect being of medium size and significant (Wilcoxon, $Z=3.429, p=$ $.0006, r=.31$ ).

In more detail, in terms of the white participants, we find that the outgroup estimation is positive (M OUTWhite: 42.45, Mdn OUTWhite: 46.00). The adjectives most frequently associated with this representation (eg "fast", "big", "smiling", "sporty", "endurance", "muscular" etc.) have positive connotations, with the exception of "poor" and "racist". This estimation of the participants of the White group about the out-group is more favorable than the estimations about their own group ( $\left.M_{I N W h i t e}: 7.96, M d n_{N W h i t e}: 0.00\right)$; the Wilcoxon test indicates that this result is significant and the effect is large $(Z=5,604 ; p=$ $.0000 ; r=.60)$.

For the participants of the Black group, on the other hand, the estimation of the in-group ( $\left.M_{\text {INBlack }}: 35.11, M d n_{\text {INBlack }}: 24.65\right)$ is significantly $(Z=2.402 ; p$ $=.032, r=.43$ ) more favorable than the estimation of the out-group (MOUTBlack: 2.87, Mdn $n_{\text {OUTBlack }}: .000$ ), the effect being of medium size. In terms of the adjectives used to describe white people, it is rather a mixed picture with the participants of the Black group, with around half being negative characteristics: 
"hypocrite", "racist" and "selfish", the others being good qualities: "smart", "kind"and "hard-working".

It is important to note that, of the total white participants questioned, $10.53 \%$ refused to answer as they believed the tool was "racist", while none of the black participants questioned did so $(\mathrm{p}=.056$ to the exact probabilities of the Fisher test - one tailed).

\section{Discussion}

Our approach proposed a different treatment of interethnic relations for the participants depending on the group they belonged to. The results of the baseline estimation effect shows that there is a consensus about the interethnic relational context between Black and White, or rather the two groups of participants viewed this in the same way.

Conversely, the results highlight the difference felt by the participants between the in-group and the out-group. In more detail, the estimations given by the participants for the out-group and the in-group show that the white participants judged the Black category more positively than the black participants judged the White category. An asymmetry therefore clearly exists in the estimation of relations. There appeared to be an out-group favoritism strategy for the participants of the White group.

This result may seem surprising because the theories of social identity and social categorization (Castel 2007, Lacassagne et al. 2001, McGarty and Turner 1992, Tajfel and Turner 1986, Tajfel 1972, Turner et al. 1994, Turner 1991) all arrive at a need to develop a positive social identity by favoring the in-group at the expense of the out-group.

However, the positive estimation made by the white participants about the out-group could be seen as the expression of the anti-racist norm found in the major effect of Prejudgment. In this last case, the behavior adopted does not imply adopting a disadvantageous position in a difficult intergroup relationship, but, quite the contrary, adopting the most highly regarded position.

The White group lives in a "white world" in which white people occupy a "privileged" position, i.e. non-threatening to their identity (Chappe and Brauer 2009). In this world, the antiracist norm prevails and gives them the opportunity to be the "nobles" (Sachdev and Bourhis 1991). There is therefore no point in exhibiting an out-group Prejudgment bias in the estimation of black people, which could be accused of blatant racism. This point of view is even explicitly reflected in the open refusal of several potential participants to participate in this research, considering it "racist". The RepMut methodology is non-directive and equivalent for both target-groups; it is currently used in the understanding of other intergroup relations (French-Germans Young-Old or diabetics-Non- diabetics, among others) with equivalent field applications, in which there has not been such refusal. In that way, this tendency of refusal 
could be an indicator about the differences of those two groups (Black and Whites) and the particularities of interethnic context.

Furthermore, the results show that participants of the Black group were more favorable toward their group than the white participants were to theirs. This behavior corresponds to a classic in-group favoritism strategy. Black people (also living in a "white world") fall in with the antiracist norm, but $a$ contrario, did display the classic effects of categorization by favoring the group they belonged to and discriminating against the White group.

It is likely that the unavoidable color salience does not help Black/White relations in mainland France and that in a predominantly white context, this salience, which is found in the category biases of the participants of the White group, is more strongly felt by the minority group, hindering the adherence to majority norms which reinforces the sense of discrimination by the unequal positions it creates.

However, the measurements made are direct, subject to social desirability bias more than indirect ones. Yet to be explored is how the members of these two groups behave when they "talk" in the name of the members of their group, or when they consider what the out-group members think of themselves.

\section{Conclusions}

Our study highlighted the role of the antiracist norm to which the participants are subject by identifying some operating mechanisms involved in intergroup relations.

Indeed, our study, through the RepMut tool, was able to differentiate between the effects of categorization and the effect of prejudice associated with an antiracist norm. In this sense, although situated in a relatively precise location (University of Burgundy context), our study represents an advance in research on Human Sciences, aiming to understand intergroup relations in a Black-White interethnic context.

Similarly, advances in understanding intergroup relations should be compared with a study of the adjectives themselves, in terms of their order of citation, their frequency and their link to the stereotype, as well as new studies, attempting to differentiate between category-based effects and socio-normative effects such as cross-cultural effects.

Subsequently, these results may also help to progress further in the identification of the types of identity used by the participants, in terms of social partitions, consistent with advances in the RepMut methodology (Castel and Lacassagne 2005, 2011, Lacassagne et al. 2003, Perrin 2011).

\section{References}

Abrams D, Hogg MA (2004) Metatheory: lessons from social identity research. Personality and Social Psychology Review: An Official Journal of the Society for 
Personality and Social Psychology Inc 8(2): 98-106. doi:10.1207/s15327957pspr0802_2.

Abric JC (1984) L'artisan et l'artisanat: analyse du contenu et de la structure d'une représentation sociale [Artisan and crafts: Content and social structural analysis of a social representation]. Bulletin de Psychologie 37(15-17): 861-875.

Beauchemin C, Hamel C, Simon P, L'équipe-TeO (2010) Trajectoires et Origines. Enquête sur la diversité des populations en France [Trajectories and Origins. Survey on the diversity of population in France]. (Documents de travail 168). Paris, France.

Borrel C, Lhommeau B (2010) Etre né en France d'un parent immigré [Born in France by one immigrant parent]. Insee Première 1287(4).

Bourhis RY, Gagnon A (2006) Les préjugés, la discrimination et les relations intergroupes [Prejudice, discrimination and intergroup relations]. In RJ Vallerand (Ed) Les fondements de la Psychologie sociale (2nd ed): 531-598. Montreal: Canada: Chenelière Education \& McGraw-Hill.

Bourhis RY, Leyens JP (1999) Stéréotypes, discrimination et relations intergroupes [Stereotypes, discrimination and intergroup relations] (2nd ed.). Paris, France: Editions Mardaga.

Brewer MB (1979) In-group bias in the minimal intergroup situation: A cognitivemotivational analysis. Psychological Bulletin 86(2): 307.

Castel P (2007) Catégorisation sociale, stéréotypes ethniques et discours racistes [Social categorization, ethnic stereotypes and racist speech]. In JP Pétard (Ed) Psychologie Sociale: 335-392. Paris, France: Bréal.

Castel P, Lacassagne M (2005) Les partitions discriminantes dans la négociation du contrat de communication [Discriminant partitions in negotiating the communication contract]. Bulletin de Psychologie 477(3): 299-306.

Castel P, Lacassagne M-F (2011) Contrat de communication et partitions sociales [Communication and social partitions contract]. In P Castel, É Sales-Wuillemin, M-F Lacassagne (Eds) Psychologie sociale-Communication-Langage. Paris, France: De Boeck.

Chappe B, Brauer M (2009) Les stéréotypes et la variabilité perçue dans les groupes: état des lieux et enjeux [Stereotypes and variability seen in groups: current status and challenges]. L'Année Psychologique 108(01): 133. doi:10.4074/S0003503308001061.

Dovidio JF, Gaertner SL, Kawakami K (2010) Racism. In JF Dovidio, M Hewstone, P Glick, VM Esses (Eds) The SAGE Handbook of Prejudice, Stereotyping and Discrimination: 312-327. London, UK: Sage Publications.

Dovidio JF, Hewstone M, Glick P, Esses, VM (2010) Prejudice, Stereotyping and Discrimination: Theoretical and Empirical Overview. In The SAGE Handbook of Prejudice, Stereotyping and Discrimination: 3-28. Sage Publications Ltd.

Ellemers N (1993) The Influence of Socio-structural Variables on Identity Management Strategies. European Review of Social Psychology 4(1): 27-57. doi:10.1080/14792779343000013.

Fiske ST (1998) Stereotyping, prejudice, and discrimination. Handbook of Social Psychology 2: 357-411.

Flament C (2001). Structure, dynamique et transformation des représentations sociales [Structure, dynamics and transformation of social representations]. In JC Abric (Ed) Pratiques sociales et représentations (3rd ed): 37-58. Paris, France: Presses universitaires de France. 
Ghiglione R (1988) Enjeux et discours: le paradigme de la cohérence [Challenges and discourse: the paradigm of coherence]. Revue Internationale de Psychologie Sociale 1(3-4): 367-389.

Ghiglione R, Blanchet A (1991) Analyse de contenu et contenus d'analyses [ Analysis of the content and contents of the analysis]. France: Dunod.

Haslam SA (2004) Psychology in organizations: The social identity approach (2nd ed.). London, UK: Sage Publications, Inc.

Hogg MA, Abrams D, Otten S, Hinkle S (2004) The Social Identity Perspective. Small Group Research 35(3): 246-276. doi:10.1177/10464964 04263424.

Institut National de la Statistique et des Etudes Economiques (2014) Composantes de la croissance démographique [Components of population growth]. Retrieved from: http://bit.ly/1LzIDL7. [Accessed 13 March 2014].

Lacassagne M-F, Imbernon V, Jébrane A, Castel P (2003) Exploration langagière de partitions hiérarchiques [Language Exploration of hierarchical partitions]. Psychologie et Société 6: 163-175.

Lacassagne M-F, Sales-Wuillemin É, Castel P, Jébrane A (2001) La catégorisation d'un exogroupe à travers une tâche d'association de mots [The categorization of an outgroup through a word association task]. Papers on Social Representations 10(7): $1-7$.

Le Bouedec G (1984) Contribution to the methodology of the study of social representations. Current Psychology of Cognition 4(3): 245-272.

McGarty C, Turner JC (1992) The effects of categorization on social judgement. British Journal of Social Psychology 31: 253-268. doi:10.1111/ j.20448309.1992.tb00971.x.

Moscovici S (1984) The phenomenon of social representations. In R Farr, S Moscovici (Eds) Social Representations. Cambridge/Paris: Cambridge University Press/Maison des Sciences de l'Homme.

Ndobo A (2010) Les nouveaux visages de la discrimination [The new faces of discrimination]. (1st ed.). Paris, France: De Boeck.

Perrin C (2011) Dynamique identitaire et partitions sociales: le cas de l'identité "raciale" des noirs en France [Identity dynamics and social partitions: the case of "racial" identity of blacks in France]. Laboratoire SPMS. Université de Bourgogne, Dijon.

Rothbart M, Taylor M (1992) Category labels and social reality: Do we view social categories as natural kinds?. In GR Semin, K Fiedler (Eds) Language, interaction and social cognition: 11-36. Thousand Oaks, CA, US: Sage Publications, Inc.

Sachdev I, Bourhis RY (1991) Power and status differentials in minority and majority group relations. European Journal of Social Psychology 21(1): 1-24. doi:10.1002/ejsp.2420210102.

Tajfel H (1972) La catégorisation sociale [Social categorization]. Introduction À La Psychologie Sociale 1: 272-302.

Tajfel H (1978) Differentiation between social groups: Studies in the social psychology of intergroup relations, european monographs in social psychology. London: Academic Press.

Tajfel H, Billig MG, Brundy RP, Flament C (1971) Catégorisation sociale et comportement intergroupes [Social categorization and intergroup behavior]. European Journal of Social Psychology 1: 149 - 178.

Tajfel H, Turner JC (1986) An integrative Theory of Intergroup Conflict. In WG Austin, S Worchel (Eds) Psychology of intergroup relations: 7-24. Monterrey, CA: Brooks/Cole. 
Turner JC (1991) Social influence. Belmont, CA, US: Thomson Brooks/Cole Publishing Co.

Turner JC, Oakes PJ, Haslam SA, Mcgarty C (1994) Self and collective: Cognition and social context. Personality and Social Psychology Bulletin 20: 454.

Van Knippenberg A Van (1978) Status differences, comparative relevance and intergroup differentiation. In $\mathrm{H}$ Tajfel (Ed.) Differentiation between social groups: Studies in the social psychology of intergroup relations: 171-199. London, UK: Academic Press.

Van Knippenberg A Van, Dijksterhuis A (2000) Social categorization and stereotyping: A functional perspective. In W Stroebe, M Hewstone (Eds) European Review of Social Psychology: 105-144t. Chichester, England: Wiley. 